\title{
PRAKTIK CARA BUDIDAYA CACING Lumbricus rubellus DALAM MENUNJANG BUDIDAYA IKAN LELE DI DESA KERAMAS KABUPATEN GIANYAR
}

\author{
N.M. Ernawati ${ }^{1}$, I.W. Arthana ${ }^{2}$, G.R.A. Kartika ${ }^{3}$, P.G.S. Julyantoro ${ }^{4}$, dan \\ A.P.W.K. Dewi ${ }^{5}$
}

\begin{abstract}
ABSTRAK
Salah satu pusat perikanan budidaya di Gianyar adalah di Desa Keramas. Ikan lele adalah komoditi utama di desa ini karena ikan lele merupakan salah satu komoditi perikanan tawar yang benilai ekonomis. Faktor penting yang perlu diperhatikan dalam kegiatan budidaya salah satunya adalah ketersediaan pakan. Usaha budidaya akan sulit berkembang apabila hanya menggunakan pakan buatan karena harganya yang relatif mahal. Salah satu upaya yang dapat dilakukan untuk mengatasi hal tersebut adalah mencari pakan alternatif yang bernutrisi namun harganya lebih murah. Cacing tanah (Lumbricus rubellus) adalah salah satu pakan alami yang memiliki kandungan protein tinggi dan relatif mudah untuk dibudidayakan. Oleh karena itu informasi tentang manfaat dan cara budidaya cacing tanah (L. rubellus) perlu disampaikan kepada pembudidaya ikan lele di desa Keramas melalui kegiatan pelatihan (teori dan praktik). Hasil dari kegiatan ini adalah masyarakat mendapatkan informasi tentang pakan alternatif dan mereka tertarik untuk memulai budidaya cacing untuk mendukung kegiatan perikanan terutama pada budidaya ikan lele.
\end{abstract}

Kata kunci : budidaya, cacing tanah, lele, pakan alami

\begin{abstract}
One of the centers of aquaculture in Gianyar is in Keramas Village. Catfish is the main commodity in this village because catfish is an economically valuable fresh fishery commodity. One important factor that needs to be considered in aquaculture activities is the availability of feed. The aquaculture business will be difficult to develop if only using artificial feed because the price is relatively expensive. One effort that can be done to overcome this is to find nutritious alternative feed but the price is cheaper. Earthworm (Lumbricus rubellus) is a natural food that has high protein content and is relatively easy to be cultivated. Therefore information about the benefits and ways of cultivating earthworms (L. rubellus) needs to be conveyed to catfish farmers in Keramas village through training activities (theory and practice). The result of this activity was that the community gets information about the alternative feeds and they interest to starts worm cultivation to support fisheries activity, especially in catfish farming..
\end{abstract}

Keywords: cultivation, worm, catfish, natural feed.

${ }^{1}$ Program Studi Manajemen Sumberdaya Perairan, FKP, Universitas Udayana, ernawati@unud.ac.id. ${ }^{2}$ Program Studi Manajemen Sumberdaya Perairan, FKP, Universitas Udayana, iwarthana60@yahoo.co.id ${ }^{3}$ Program Studi Manajemen Sumberdaya Perairan, FKP, Universitas Udayana, raka.angga.k@ unud.ac.id ${ }^{4}$ Program Studi Manajemen Sumberdaya Perairan, FKP, Universitas Udayana, pande.sasmita@unud.ac.id ${ }^{5}$ Program Studi Manajemen Sumberdaya Perairan, FKP, Universitas Udayana, ayuputu72@gmail.com 


\section{PRAKTIK CARA BUDIDAYA CACING LUmbricus rubellus DALAM MENUNJANG BUDIDAYA IKAN LELE DI DESA KERAMAS KABUPATEN GIANYAR}

\section{PENDAHULUAN}

Budidaya ikan lele sudah dikenal sejak lama di Indonesia karena ikan ini memiliki nilai ekonomi tinggi. Menurut Khairuman dan Amri (2002), masuknya jenis lele dumbo (Clarias sp.) ke Indonesia merupakan awal meningkatnya usaha budidaya ikan lele di negara ini. Lele dumbo memiliki rasa yang enak dan kandungan gizi yang tinggi dengan harga yang cukup terjangkau oleh masyarakat. Selain itu lele dumbo mudah berkembang biak dan memiliki pertumbuhan yang relatif cepat (Jaja dkk., 2013). Ferdian dkk. (2012) menambahkan bahwa ada beberapa faktor yang menyebakan produksi lele dumbo meningkat diantaranya adalah modal usaha yang dibutuhkan relatif rendah dan pemasarannya relatif mudah, teknologi budidayanya tidak terlalu sulit dan mudah dikuasai oleh masyarakat bahkan bisa dibudidayakan pada lahan dan sumber air yang terbatas dengan padat tebar yang tinggi. Selain itu penyediaan pakan tidak terlalu sulit karena ikan lele menyukai berbagai jenis pakan.

Ikan lele sangat disukai oleh masyarakat di Indonesia karena memiliki beberapa kelebihan baik rasa maupun kandungan gizi. Ikan lele memiliki daging yang lunak, rasa yang khas, enak dan gurih serta mengandung 18,2 gram protein setiap 100 gram daging lele. Protein tersebut sangat bermanfaat bagi tubuh manusia selain sebagai penambah jumlah protein konsumsi, dalam pola makan juga berfungsi sebagai pelengkap mutu protein (Purwono dkk., 2011).

Peningkatan kebutuhan pangan akan selalu beriringan dengan peningkatan jumlah penduduk. Begitu pula dengan permintaan lele dumbo (Clarias sp.) yang semakin meningkat dari tahun ke tahun sebagai dampak ikutan dari peningkatan jumlah penduduk. Akan tetapi target produksi perikanan berdasarkan data Kementerian Kelautan dan Perikanan tahun 2012 belum terpenuhi (hanya tercapai $82,36 \%$ ). Pengembangan budidaya lele di Bali masih sangat menjajikan karena hasil produksi lele di Bali sendiri masih belum bisa memenuhi permintaan pasar. Kekurangan kebutuhan lele di Bali dipasok dari beberapa daerah lain yaitu Jember, Banyuwangi dan Situbondo (Sudana dkk., 2013).

Salah satu kelompok yang sedang mengembangkan budidaya ikan lele di Provinsi Bali berada di Kabupaten Gianyar, tepatnya di Desa Keramas dengan nama kelompok pembudidaya ikan lele Poh Gending Center. Saat ini terdapat 15 orang yang memiliki mata pencaharian sebagai pembudidaya ikan lele yang tergabung dalam kelompok tersebut. Saat ini Kelompok Poh Gending Center sudah memiliki 30 petak kolam lele yang dikelola secara bersama-sama.

Salah satu kunci keberhasilan budidaya ikan lele adalah optimalisasi pemberian pakan. Usaha budidaya perikanan pada umumnya lebih banyak membutuhkan biaya untuk pembelian pakan dari pada biaya produksi lainnya. Pakan merupakan hal yang sangat penting diperhatikan dalam kegiatan budidaya ikan, baik secara semi intensif maupun intensif karena pakan merupakan komponen biaya produksi yang paling tinggi yaitu sekitar 35-70\% dari biaya operasional (Webster dan Lim, 2002). Saat ini banyak kegiatan budidaya sulit berkembang karena terkendala oleh harga pakan buatan yang relatif mahal. Untuk mengatasi hal tersebut, para pembudidaya memerlukan alternatif pakan lain yang harganya lebih murah namun mengandung nutrisi yang cukup yang diperlukan oleh ikan.

Salah satu pakan alami sebagai pakan alternatif bagi ikan dengan kandungan protein tinggi adalah cacing tanah (L. rubellus) (Pucher et al., 2012; Istiqomah et al., 2009). Cacing tanah relatif mudah dan murah untuk dibudidayakan karena hanya membutuhkan tanah dan kompos sebagai medianya. Oleh karena itu, kombinasi pakan buatan dengan cacing tanah sangat cocok dijadikan solusi untuk meminimalisasi pengeluaran untuk pembelian pakan. Selain itu, menurut Ernawati dkk. (2017), budidaya cacing tanah belum banyak dikembangkan di Bali sehingga memiliki potensi yang baik untuk dikembangkan sebagai peluang usaha. 


\section{METODE PELAKSANAAN}

Kegiatan dilaksanakan di lokasi budidaya yang juga merupakan tempat pertemuan pembudidaya ikan lele Poh Gading Senter, Desa Keramas, Kabubaten Gianyar, Bali. Pelaksanaan kegiatan dilakukan dalam 2 sesi yaitu pemaparan teori dan dilanjutkan dengan praktik. Teori yang diberikan berisi tentang keuntungan budidaya cacing, L. rubellus, alat dan bahan untuk bidudaya cacing, syarat media dan cara fermentasi media budidaya cacing, serta cara pemanenan cacing. Praktik cara budidaya cacing dilakukan dengan meberikan contoh terlebih dahulu kemudian dilakukan sendiri oleh para peserta kegiatan.

\section{HASIL DAN PEMBAHASAN}

Kelompok Perikanan Poh Gading Senter, Desa Keramas, Kecamatan Blahbatuh, Kabupaten Gianyar dibentuk berdasarkan musyawarah dan mufakat dari anggota masyarakat yang bergerak dibidang perikanan terutama pada budidaya perikanan lele. Fungsi kelompok adalah sebagai suatu wadah bekerjasama, tempat usaha (produksi) dan wahana belajar bagi anggota kelompok, sehingga dapat diharapkan pengelolaan dan pemanfaatan sumberdaya perikanan terutama budidaya perikanan lele guna menunjang kehidupan dan penghidupan masyarakat serta terjaganya kelestarian dalam upaya pembangunan yang berkelanjutan, khususnya dibidang budidaya perikanan lele dan umumnya pada pembangunan nasional. Berdasarkan atas fungsi tersebut maka dipandang perlu untuk dibentuk Kelompok Perikanan Poh Gading Senter. Kelompok perikanan poh gading center merupakan salah satu kelompok yang memiliki kemauan dan semangat untuk membangun kegiatan perikana khususnya budidaya lele yang lebih baik. Sehingga kegiatan pengabdian ini sangat tepat dilakukan di kelompok perikanan ini.

Kegiatan "Praktik Cara Budidaya Cacing Lumbricus Rubellus dalam Menunjang Budidaya Ikan Lele Di Desa Keramas Kabupaten Gianyar" terlaksana melalui beberapa tahapan, yaitu:

1. Survei Lokasi, Diskusi Permasalahan dan Rencana Kegiatan Pelatihan

Survei lokasi dan diskusi permasalahan serta rencana kegiatan pelatihan dilakukan untuk menggali informasi-informasi terkait kegiatan budidaya dan permasalahannya serta untuk menetapkan waktu yang tepat untuk mengadakan pelatihan budidaya Cacing L. rubellus di kelompok tersebut. Survei ini meliputi beberapa diskusi dengan hasil sebagai berikut :

a. Survei lokasi dan melakukan diskusi ke pembudidaya ikan lele Poh Gending Center Desa Keramas Kabupaten Gianyar. Melalui survei lokasi diperoleh informasi bahwa kelompok ini memeiliki potensi yang cukup tinggi untuk pengembangan kegiatan budidaya. Kelompok Pembudidaya Ikan yang diketuai oleh Bapak Made Suastika dan memiliki anggota kurang lebih sekitar 15 orang dan rata-rata masih berusia cukup muda, shingga memiliki semangat yang tinggi guna pengembangan komoditas perikanan khususnya ikan lele. Berdasarkan hasil wawancara diketahui bahwa pemilihan komoditas ikan lele disebabkan karena permintaan produk ikan lele khususnya di sekitar Kabupaten gianyar sangat tinggi. Beberapa latar belakang lainnya adalah waktu pembudidayaan yang tidak terlalu lama, serta tidak memerlukan modal besar dalam pemeliharaannya. Fokus kegiatan yang dilakukan pada kelompok ini adalah pada usaha pembenihan dan pembesaran ikan lele. Kelompok ini memiliki 2 lokasi kolam yang berbeda untuk kedua kegiatan tersebut.

b. Melakukan diskusi mengenai permasalahan-permalsahan yang dihadapi oleh kelompok perikanan Poh Gending Center. Terdapat beberap masalah utama yang sering dihadapai kelompok ini, antara lain adalah:

- Jumlah telur yang dihasilkan sangat bervariasi tergantung kondisi air dan cuaca

- Rendahnya tingkat kelulushidupan benih ikan lele hasil pemijahan

- Tingginya harga pakan komersial yang diaplikasikan kepada benih lele 
- Ketersediaan pakan alami seperti cacing sutra pada musim-musim tertentu.

c. Diskusi mengenai waktu pelaksanaan kegiatan pengabdian yang bertujuan untuk mencarikan solusi bagi permasalahan yang sering dihadapi oleh kemlopok ini khususnya mengenai pakan alternatif yang dapat digunakan untuk menggantikan pakan pabrik ataupun pakan alami cacing sutra yang susah didapatkan

2. Pelaksanaan Kegiatan Praktik Cara Budidaya Cacing L. Rubellus

Kegiatan praktik cara budidaya cacing L. Rubellus dilaksanakan selama satu hari pada tanggal 15 September 2018. Peserta kegiatan berjumlah 50 orang yang terdiri dari anggota kelompok Pembudidaya Ikan Lele Poh Gending Center, beberapa perwakilan dari kelompok pembudidaya ikan lele lain di Kabupaten Gianyar, perwakilan Dinas Perikanan Kabupaten Gianyar, serta beberapa orang mahasiswa dari Program Studi Manajemen Sumberdaya Perairan, Fakultas Kelautan dan Perikanan Universitas Udayana. Pelaksanaan kegiatan pengabdian pelatihan budidaya cacing Lumbricus rubellus terdiri dari dua sesi yaitu :

a. Pemaparan Teori Budidaya Cacing Lumbricus rubellus

Teori tentang Cacing L. rubellus dan cara membudidayakannya disampaikan oleh Bapak Gde Raka Anggakartika, S.Pi., MP. Materi yang disampaikan berisi tentang kandungan dan maanfaat Cacing L. rubellus sebagai pakan alami bagi ikan lele serta cara membudidayakan cacing tersebut. Melalui pemaparan teori tersebut diharapkan mampu memberikan manfaat bagi para peserta, baik dari segi pengetahuan maupun keahlian dalam pembuatan pakan alternatif melalui budidaya cacing L. rubellus.

b. Praktik Budidaya Cacing Lumbricus rubellus

Praktik budidaya Cacing L. rubellus dilakukan secara bersama-sama oleh peserta. Kegiatan ini diikuti dengan serius oleh para peserta sampai kegiatan berakhir.
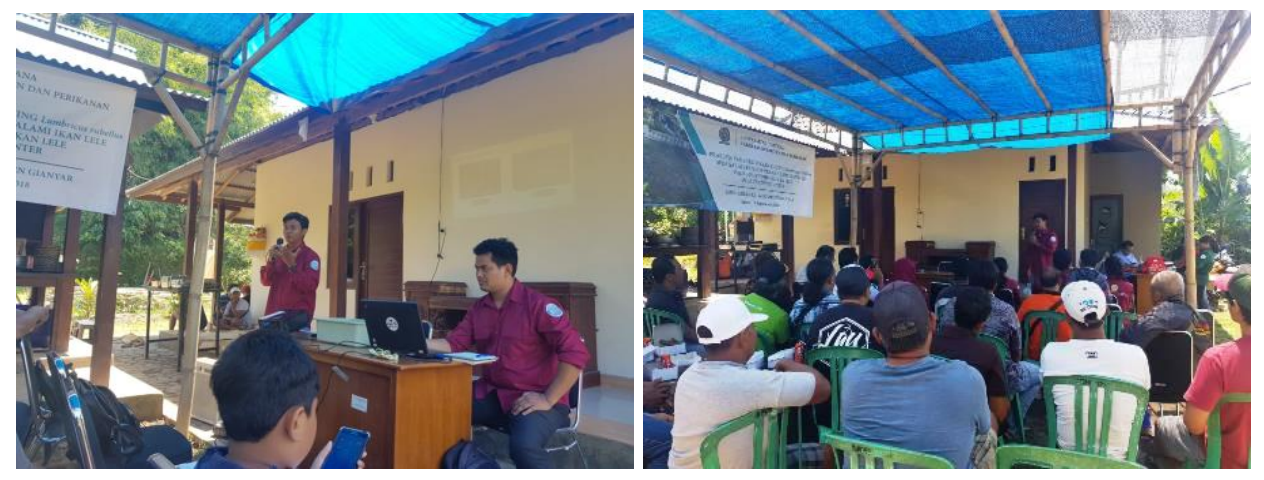

Gambar 3.1. Pemaparan Materi Budidaya Cacing Tanah
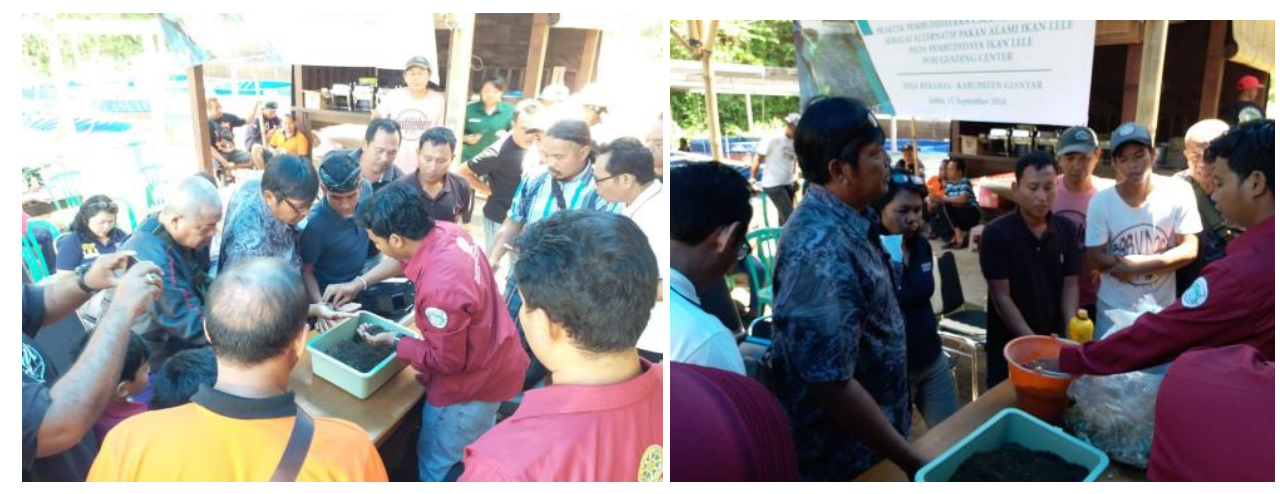

Gambar 3.1. Pratik Cara Budidaya Cacing Tanah 
3. Monitoring Hasil Pengabdian

Monitoring hasil pengabdian dilakukan seminggu setelah kegiatan pelatihan yaitu pada tanggal 23 September 2018. Monitoring dilakukan untuk mengetahui kondisi cacing yang dibudidayakan serta mengetahui keseriusan pembudidaya melanjutkan proses budidaya cacing tersebut. Hasil monitoring memperlihatkan bahwa para pembudidaya cukup serius melanjutkan budidaya cacing yang telah dipraktikan sebelumnya.

\section{KESIMPULAN}

Kegiatan "Praktik Cara Budidaya Cacing Lumbricus Rubellus dalam Menunjang Budidaya Ikan Lele Di Desa Keramas Kabupaten Gianyar" yang telah dilaksankan mendapat sambutan dan antusias yang cukup tinggi dari para peserta. Kegiatan ini dinilai sangat berguna bagi peningkatan hasil produksi ikan lele di kelompok tersebut.

\section{UCAPAN TERIMAKASIH}

Terimakasih yang sedalam-dalamnya penulis ucapkan kepada Rektor melalui LPPM Universitas Udayana yang telah membiayai dan memfasilitasi kegiatan pengabdian ini melalui skim Program Udayana Mengabdi, dengan Surat Perjanjian Penugasan Pelaksanaan Nomor : 384- 5/UN.14.4.A/PM/2018 tanggal 29 Maret 2018.

\section{DAFTAR PUSTAKA}

Ernawati, N.M., P.G.S. Julyantoro, E.W. Suryaningtyas, A.H.W. Sari, G.R.A. Kartika, S.A. Saraswati, D.A.A. Pebriani. (2017). Pelatihan Budidaya Cacing Lumbricus rubellus sebagai Alternatif Pakan Lele Berprotein Tinggi pada Pembudidaya Lele di Kec. Abiasemal, Kab. Badung. Buletin Udayana Mengabdi. Vol. 16 : 2, 179-183

Ferdian, F., Maulina, I., dan Rosidah. (2012). Analisis Permintaan Ikan Lele Dumbo (Clarias gariepinus) Konsumsi Di Kecamatan Losarang kabupaten Indramayu. Jurnal Perikanan dan Kelautan. Vol. 3 : 4, 93-98.

Istiqomah, A.L., A. Sofyan, Damayanti And H. Julendra. (2009). Amino Acid Profile of Earthworm and Earthworm Meal (Lumbricus Rubellus) for Animal Feedstuff. J.Indonesian Trop.Anim.Agric. Vol. 34 : 4, 253-257

Jaja, Suryani, A., dan Sumatadinata, K.. (2013). Usaha Pembesaran dan pemasaran Ikan Lele serta Strategi Pengembangannya di UD Sumber Rezeki Parung, Jawa Barat. Jurnal Magister Profesional Industri Kecil Menengah. Vol. 8 : 1, 45-58.

Khairuman, dan Amri, K. (2002). Budidaya Ikan Lele Dumbo Secara Intensif. Agro Media Pustaka. Jakarta.

Pucher, J., N.N. Tuan., T.T.H. Yen., R. Mayrhoferc, M.E. Matboulic and U. Fockend. (2012). Earthworm Meal as Alternative Animal Protein Source for Full and Supplemental Feeds for Common Carp (Cyprinus carpio L.). University of Hohenheim, Stuttgart, Germany, 167-168 p.

Purwono, J., Sugyaningsih, S., Wibowo, A. E. (2011). Strategi Pengembangan Usaha Pembesaran Ikan Lele Sangkuriang (Clarias gariepinus strain sangkuriang) di Kecamatan Ciampea Kabupaten Bogor. Fakultas Ekonomi dan Manajemen. Institut Pertanian Bogor, Bogor.

Sudana, S.N., Arga, I.W., dan Suparta, N. 2013. Kelayakan Usaha Budidaya Ikan Lele Dumbo (Clarias gariepinus) dan Pengaruhnya terhadap Tingkat Pendapatan Petani Ikan Lele di Kabupaten Tabanan. Jurnal Manajemen Agribisnis. Vol. 1 : 1, 2355-0759.

Webster, C.D. and Lim C. (2002). Nutrient Requirements and Feeding of Finfish for Aquaculture. CABI Publishing, New York. USA. 